\title{
Lewis Barnavelt and the Rainbow over New Zebedee: Queering The House with a Clock in Its Walls
}

\section{Abstract:}

The paper discusses The House with a Clock in Its Walls (1973) by John Bellairs and its film adaptation, directed by Eli Roth (2018), from queer theory and gender studies perspectives. The author of the article aims to overview and develop existing queer interpretations of the first novel in the Lewis Barnavelt series, with contextual references to the cycle's subsequent volumes, and to conduct a queer theory-inspired analysis of Roth's motion picture. The genre represented by the novel and the film is also considered by taking the scholarly reflections on the queer aspects of the Gothic and the horror into account. The author concludes that although both versions of the story fail at portraying femininity in an unconventional way, they succeed in showing that queerness and, more generally, the Otherness should be highly appreciated and valued.

\section{Key words:}

adaptation, American Gothic, children's and young adult film, children's and young adult literature, Eli Roth, gender studies, Gothic fiction, horror, John Bellairs, Lewis Barnavelt, queer theory, The House with a Clock in Its Walls

\section{Lewis Barnavelt i tęcza nad New Zebedee. Queerowanie Zegara czarnoksiężnika}

\section{Abstrakt:}

Artykuł rozpatruje powieść Zegar czarnoksiężnika (1973) Johna Bellairsa i filmową adaptację tego utworu w reżyserii Elia Rotha (2018) z perspektywy teorii queer oraz

* Maciej Skowera - MA, prepares a doctoral dissertation at the Institute of Polish Literature of the Faculty of Polish Studies at the University of Warsaw (Poland) on the presence of Lewis Carroll's Alice duology, L. Frank Baum's Oz series, and J. M. Barrie's Peter Pan works in the cultural imaginarium. He works at the Museum of Children's Books in Warsaw. Contact: maciej.skowera@koszykowa.pl.

1 The article was written during the author's stay in Munich at the International Youth Library (Internationale Jugendbibliothek) as part of the fellowship programme funded by the Federal Foreign Office of the Federal Republic of Germany. 
gender studies. Celem autora tekstu jest zaprezentowanie i rozwinięcie wcześniejszych queerowych interpretacji pierwszej powieści z cyklu o Lewisie Barnavelcie i, kontekstowo, kolejnych tomów serii, jak również przeprowadzenie inspirowanej teorią queer analizy filmu Rotha. W artykule, poprzez odwołanie się do naukowej refleksji na temat queerowych aspektów literatury gotyckiej i horroru, poruszona zostaje również kwestia gatunku reprezentowanego przez powieść i film. Autor dochodzi do wniosku, że mimo iż obie wersje tej historii nie radzą sobie z ukazywaniem kobiecości w niekonwencjonalny sposób, to udaje im się zaprezentować queerowość oraz, szerzej, Inność jako wartości, które powinny być wysoko cenione.

\section{Słowa kluczowe:}

adaptacja, amerykański gotyk, film dziecięcy i młodzieżowy, literatura dziecięca i młodzieżowa, Eli Roth, gender studies, literatura gotycka, horror, John Bellairs, Lewis Barnavelt, teoria queer, Zegar czarnoksiężnika

\section{Introduction: Is There a Queer in This Text?}

A mong the comments on Grady Hendrix's (2013/2018) web article "The which simply praise the titular author and his novel, one clearly stands out. Steve Berman (2018), a user, writes as follows: "A friend of mine said there is a great deal of gay sub-text in the film. I'd be curious if the book was ever approached from a queer theory aspect [emphases added]; I'm going to have to reread it. I forget if the sexuality of Bellairs was ever stated." This comment alludes to the first book in the Lewis Barnavelt series, The House with a Clock in its Walls by John Bellairs (1973/1998b), and its film adaptation of the same title (Fischer, Vanderbilt, Kripke, \& Roth, 2018). ${ }^{2}$ Putting aside the last sentence in the quoted statement, ${ }^{3}$ it may be surprising for some that the film, directed by Eli Roth from a screenplay by Eric Kripke, indeed lends itself readily to a queer interpretation and that Bellairs's novel itself has already been analysed from a queer theory perspective.

There is an ongoing discussion - largely inspired by such landmark yet controversial works as the ones by Jacqueline Rose (1984), James R. Kincaid (1992), Eve Kosofsky Sedgwick (1993), Michael Moon (1998), or Kathryn Bond

2 The book was previously adapted as a part of a CBS television special Once Upon a Midnight Scary (Asselin, Asselin, \& Cox, 1979).

3 As far as I know, there is no evidence that John Bellairs was a queer person. He was married in 1968 to Priscilla Braids, whom he later divorced. The couple had a son named Frank (McElmeel, 1999, p. 31). 
Stockton (2009) - about the possibilities of applying queer theory to children's literature and, more generally, culture. ${ }^{4}$ The elements of the debate take various forms, from descriptive and critical essays through case studies to comparative analyses (Abate \& Kidd, 2011; Bruhm \& Hurley, 2004; Jarkovská, 2014; Kidd, 2004, 2011; Lesnik-Oberstein, 2016; Lesnik-Oberstein \& Thomson, 2002; Pugh, 2011). Melynda Huskey (2011) writes that:

One of the tasks queer theory undertakes is revealing and interpreting the queer subtexts and underpinnings of 'straight' discourse, 'queering' the apparently straight. Following out the clues in books, television, and film that reveal the presence of the unspoken, the code that simultaneously connects and alienates the queer reader, is one critical practice which characterizes queer theoretical readings.

In this paper, however, I intentionally avoid using the notion of 'subtext.' I agree with Alexander Doty (1993) that queer readings are not subordinate to heteronormative readings of cultural texts - as the scholar writes:

After all, the queerness I point out in mass culture representation and reading [...] is only 'connotative,' and therefore deniable or 'insubstantial' as long as we keep thinking within conventional heterocentrist paradigms, which always already have decided that expressions of queerness are sub-textual, sub-cultural, alternative [emphases in original] readings, or pathetic and delusional attempts to see something that isn't there - after all, mass culture texts are made for the 'average' (straight, white, middle-class, usually male) person, aren't they? I've got news for straight culture: your readings of texts are usually 'alternative' ones for me, and they often seem like desperate attempts to deny the queerness that is so clearly a part of mass culture (p. xii).

Even though many children's literature and culture-oriented scholars criticise particular aspects of queer theory's approach towards juvenile cultural texts, such as the problematic issue of essentialising the 'proto-gay child' (Lesnik-Oberstein \& Thompson, 2002) or that of the child's gender identity in general (Vassiloudi, 2016), others tend to approve or, at least, accept it. Some critics also stress the similarities between queer theory and children's literature

4 Although one might claim that the Lewis Barnavelt cycle is a young adult series (Hahn, 2015), these books are more often classified as children's literature (Broughton, 2001; Duffy, 2004; Heinecken, 2011; Huskey, 2010; Schmidt, 1987), targeted especially to middle grade preteens and early teens. 
studies. Kenneth Kidd (2011), for instance, asks whether the latter one can be "positioned as already [emphasis in original] a queer theory of sorts," constituting "not simply [...] a field of literature but [...] a theoretical site in its own right” (p. 186), while Maria Nikolajeva (2010) coins the term 'aetonormativity' - which denotes an "adult normativity that governs the way children's literature has been patterned from its emergence until the present day" (p. 8) - drawing on the concept of 'heteronormativity,' popularized by Michael Warner (1991). ${ }^{5}$

Nevertheless, it can be argued that, outside academia (particularly the Western one), linking childhood and queerness is often still perceived as an 'unacceptable' practice, whether it is because of a particular country's official politics towards queer people or, more generally, due to children's 'innocence' and 'non-sexuality' imagined and constructed in the West by adults (Kehily \& Montgomery, 2009). Although the voices about the need for openly queer children's books are heard, such works often arouse controversies, especially in more conservative societies. In the Western world, the examples would be Poland (Perdzyńska, 2010) and Italy (Illuminati, 2016), in which the public sphere is strongly influenced by the traditionalist worldview conditioned by, inter alia, the high position of the Catholic Church. Moreover, there are discussions frequently triggered by the attempts to search for queerness, most notably in children's classics. It is, I argue, even more in question to create a new film or book basing on a canonical work commonly associated with children that shows well-known characters, usually imagined as heteronormative, as implicitly or explicitly queer figures. In the contexts of TV and cinema, one can mention the controversies over Dorothy Gale's and Red Riding Hood's lesbian kiss in the $\mathrm{ABC}$ family-friendly primetime drama Once Upon a Time (Chambliss, Wolkoff, \& La Salle, 2016) ${ }^{6}$ or over the portrayal of LeFou as a most likely

5 However, as Clémentine Beauvais (2015) puts it: “Oppressed and hegemonic groups which have presentness [emphasis in original] for one another - women and men, the proletariat and the bourgeoisie, animals and humans - are different from adults and children. Feminist, queer, postcolonial, Marxist, etc. political and literary theories envisage the transformation of the oppressed group's status. This is not the case for, if I may coin a Nikolajeva-inspired term, 'aetocriticism' or 'aetotheory' - the analysis of generational or age relationships. The status of the child vis-à-vis the adult is always already one of transformation: it is constantly being modified towards adulthood" (p. 18).

6 The episode in which the kiss takes place was protested by several 'traditional values' groups, like One Million Moms (Chubb, 2016), and conservative bloggers, such as Geoffrey Grider (2016, as quoted in Chubb, 2016) who asks: "Why is a show [...] marketed to children [...] now promoting graphic lesbianism?," and answers his own question: "Because these are the end times, and the tide of darkness and evil is rising until the cup is filled." 
queer person in Disney's live-action Beauty and the Beast (Hoberman, Lieberman, \& Condon, 2017). ${ }^{7}$

In this context, it is interesting, and even surprising, that the premiere of the screen version of The House with a Clock in Its Walls has not aroused such controversies in this respect. ${ }^{8}$ I perceive the film as being overtly queer, even more - in some of its aspects - than Bellairs's book. In this paper, I will outline and develop existing queer interpretations of the first novel in the Lewis Barnavelt series, with some references to the subsequent volumes, and propose a queer theory-inspired analysis of Roth's film; gender studies approaches will also be used. I will consider the genre represented by the novel and the film too, taking the scholarly reflections on the queer aspects of the Gothic and the horror ${ }^{9}$ into account. It is important to note that, here, 'adaptation' is understood as a recasting of an original work in a new form (Oittinen, 2006, p. 10) that "involves both (re-)interpretation and (re-)creation" (Hutcheon, 2006, p. 8) in the course of "an announced and extensive transposition of a particular work or works," in this case: with a "shift of medium" (p. 7). The changes between the source material and the final product of the process are unavoidable, as "there

7 As Gwilyn Mumford (2017) writes: "In the new version of Beauty and the Beast the character of LeFou, the sidekick of the story's villain Gaston, is 'confused about his sexuality,' according to director Bill Condon. The film features an 'exclusively gay moment,' where LeFou dances with another man." Because of this scene and its interpretation, the film was released with a 16+ rating in Russia, banned in one Alabama cinema, supposed to be cut (but eventually was not) in Malaysia, and not screened in Kuwait (Raghavan, 2017).

8 The film, however, was found offensive by some due to its depiction of occultism and witchcraft, including necromancy. See, for instance, Bishop (2018).

9 As observed by Clive Bloom (2012), “while 'horror' and 'Gothic' are often (if not usually) interchangeable, there are, of course, Gothic tales that are not horror fiction [...] and horror tales that contain no real Gothic elements" (p. 211). What is more, generally, "Gothic fictions [...] play with and oscillate between the earthly laws of conventional reality and the possibilities of the supernatural [...] often siding with one of these over the other in the end, but usually raising the possibility that the boundaries between these may have been crossed, at least psychologically but also physically or both. This oscillation can range across a continuum between what have come to be called the 'terror Gothic' on the one hand and the 'horror Gothic' on the other. The first of these holds characters and readers mostly in anxious suspense about threats to life, safety, and sanity kept largely out of sight or in shadows or suggestions from a hidden past, while the latter confronts the principal characters with the gross violence of physical or psychological dissolution, explicitly shattering the assumed norms (including the repressions) of everyday life with wildly shocking, and even revolting, consequences" (Hogle, 2002, pp. 2-3). Here, I assume that the words 'Gothic' and 'horror' may refer to different kinds of narratives, and when they overlap, we can call a certain work a Gothic horror. 
is no one-to-one correspondence between signs of the systems of literature and cinema" (Helman \& Osadnik, 1996, p. 646).

Queer adaptations, when understood in a wider sense, can be defined as "adaptations that are about [emphasis in original] homosexuality (or non-normative sexual or gender identity more broadly), composed or adapted by queer authors, and consumed by queer audiences and readers" (Demory, 2018, p. 146). In my view, Roth's cinematic adaptation of The House with a Clock in Its Walls, while not made by a queer author, is certainly about non-normative identities and, what is more, is a potential object of (proto-)queer consumption. The film uses "queer as something that inheres in a [primary] text" rather than providing "a commentary on the silenced queerness of the source text" (pp. 148-149). However, I see this version of the story as going in a different direction than Bellairs's book in presenting/hinting at queerness. Therefore, I would also like to examine how an already queer book has been adapted for a film which is both more progressive in some of its aspects and more reactionary in the others than its source material when it comes to constructions of gender.

\section{The Houses with Queers in Their Walls}

In John Bellairs's books, Lewis Barnavelt is an obese, shy, nerdy, and clumsy boy who loves books and hates sports of all sorts. In 1948, when he is ten years old, his parents die. In The House with a Clock in Its Walls, the youngster arrives to the fictional town of New Zebedee in Michigan where he is to live in a huge, mysterious mansion, owned by his uncle, red-bearded and eccentric Jonathan van Olden Barnavelt. Shortly afterwards, still at the beginning of the book, it turns out that the man is a good warlock, and that his neighbour and best friend, elderly, purple-loving Mrs. Florence Zimmerman, is a good witch too. In New Zebedee, Lewis has to face many dangerous challenges. These usually lead him to save himself, his family and friends, or even the whole world, from death and destruction (Skowera, 2016, p. 22). In the cycle's first instalment, the boy and his companions have to solve the mystery of the titular doomsday clock, hidden somewhere in the Barnavelts' property, which was constructed by an evil wizard Isaac Izard, the mansion's former occupant, to "set all the world on fire upon an instant" (Bellairs, 1973/1998b, p. 221). At the end of The House with a Clock in Its Walls, Lewis befriends Rose Rita Pottinger, a sporty girl who detests wearing skirts and who, in the later volumes of the series, becomes a full-fledged heroine. Some of Bellairs's novels are even focused mainly on her adventures (Skowera, 2016, p. 22). 
New Zebedee itself, only seemingly sleepy and ordinary, is a domain of hidden terror, similarly to other locations that Lewis and Rosa Rita visit in the subsequent books - also in the ones completed or entirely written by Brad Strickland, who revived the series after its creator's death in $1991^{10}$ - such as rural Pennsylvania in The Ghost in the Mirror (Bellairs \& Strickland, 1993a) or a gloomy English manor from The Vengeance of the Witch-Finder (Bellairs \& Strickland, 1993b). In the diegetic world of the series, there are some 'holes' and 'fissures' in the matter of the universe, through which the supernatural enters the previously peaceful, orderly, normative human ecumene (Slany, 2016, p. 84). On the one hand, the evil, as typically happens in horror fiction (Aguirre, 1990; Wein, 2000), dwells in significant spaces and places, such as a cemetery, a forgotten opera house, an abandoned farm or, in the first novel, the Barnavelts' Gothic mansion. On the other hand - it can be evoked by enchanted items, such as a magical coin, a charmed ring, or a cursed scroll. The danger is also variously represented: Lewis, Rose Rita, Uncle Jonathan, and Mrs. Zimmerman fight, for example, insane necromancers and a terrifying witch-hunter (Skowera, 2016, p. 23). ${ }^{11}$

As Dawn Heinecken (2011) states, The House with a Clock in Its Walls and the other two 'original' novels in the Lewis Barnavelt series are often perceived as "exemplary works initiating the development of supernatural mystery for children," and Bellairs seems to still have a "continued significance as a major writer of children's horror" (p. 119). Nowadays, potential readers may choose from a wide range of spooky narratives for children, which is a phenomenon widely discussed by the scholars in the field (Abbruscato \& Jones, 2014; Jackson, Coats, \& McGillis, 2008; McCort, 2016; Slany, 2016). However, in the 1970s

10 The creator of the series managed to finish only three Lewis Barnavelt books: The House with a Clock in Its Walls (Bellairs, 1973/1998b), The Figure in the Shadows (Bellairs, 1975/1998a), and The Letter, the Witch, and the Ring (Bellairs, 1976/1998c). In the 1990s, Strickland, basing on Bellairs's notes, finished three books started by his predecessor: The Ghost in the Mirror (Bellairs \& Strickland, 1993a), The Vengeance of the Witch-Finder (Bellairs \& Strickland, 1993b), and The Doom of the Haunted Opera (Bellairs \& Strickland, 1995). Additionally, he authored another six books in this now duodecalogy: The Specter from the Magician's Museum (Strickland, 1998), The Beast Under the Wizard's Bridge (Strickland, 2000), The Tower at the End of the World (Strickland, 2001), The Whistle, the Grave, and the Ghost (Strickland, 2003), The House Where Nobody Lived (Strickland, 2006), and The Sign of the Sinister Sorcerer (Strickland, 2008).

11 However, in the books, including the ones by Strickland, the sense of fear is "mediated by humorous elements and a reassuring message of adult love and protection" (Heinecken, 2011, p. 119), and by carnivalesque ridicule of horror topical figures and requisites (Skowera, 2016, pp. 31-33; Slany, 2016, pp. 195-208), which also applies to the film by Roth. 
in the United States, Bellairs's books, as "featuring disturbing and uncanny imagery and plots revolving around ghosts, witches, possession, and the resurrection of the dead, [...] emerged as a significant contrast to the serene tone of children's literature in the first two-thirds of the twentieth century" (Heinecken, 2011, p. 119). ${ }^{12}$

The genre represented by the Lewis Barnavelt novels - the Gothic horror or, more precisely, the American Gothic horror ${ }^{13}$ - is particularly important in the context of queer reading of these books. Heinecken (2011) stresses that "horror is a constantly evolving genre, whose shifting forms and content express the uncertainties haunting a society at any given time; it has been particularly expressive of fears related to gender and sexuality" (p. 119), while John Edgar Browning (2017) writes that "queer studies has [...] seen several key players [...] who have focused on theories of deviant representation and difference both in horror cinema and in literature of the Gothic(s)" (p. 100). ${ }^{14}$ Piotr Sobolczyk (2014) highlights that the English Gothic "was one of the first moral phenomena and modes of speaking in European culture in which suppressed, hidden, relegated homosexuality was allowed to come to the fore" (p. 71). ${ }^{15} \mathrm{He}$ argues that the Gothic suggests that every person - and every family - has their own 'dark secrets,' and writes that this may be the reason for the scholarly predilection towards using Sigmund Freud's categories of the 'uncanny' (das Unheimliche) or the 'return of the repressed' when analysing this kind of fiction (p. 72). The critic develops this as follows:

Homosexuality [...] was the 'repressed' in European culture. Various stages of the Gothic aesthetics, having coded diverse phases of the 'return' [of the 'repressed'], may have coincided with liberation narratives, including gay and lesbian or the fetishistic ones, etc. [...] in the context of the subject of the 'secret' $[\ldots]$, one can use an expression from [...] the Gothic repertoire: to have a skeleton in the closet [...]. The etymology of the phrase 'to come out of the closet'

12 In the 1970s in the USA, Zilpha Keatley Snyder and Phyllis Reynolds Naylor also created children's horrors that gained both critical acclaim and much popularity among readers (Heinecken, 2014, p. 68).

13 Here, the American Gothic is understood as a special kind of Gothic fiction that emerged in America in the $19^{\text {th }}$ century and was initially represented by such authors as Charles Brockden Brown or Edgar Allan Poe. I write more about it in the subsequent paragraphs of the paper.

14 To mention the works by Eve Kosofsky Sedgwick (1985), Harry M. Benshoff (1997), and George Haggerty (2006).

15 All translations, if not otherwise indicated, are made by the author of the paper - Maciej Skowera. 
as meaning 'to reveal one's sexuality' [...] according to one theory [...] has its origins in the Gothic source. [...] homosexuality [...] - also in the post-Gothic period - has been taking the form of a corpse hidden in the closet [...] often. The Gothic [...] highlights that, potentially, this applies to all. Only the spaces of the 'disclosure' change (Sobolczyk, 2014, pp. 74-75).

The classics of English Gothic literature, namely works by Horace Walpole, Matthew G. Lewis, Clara Reeve, Ann Radcliffe, or James Hogg, have been frequently interpreted in this manner. However, the discussed mode of reading can also be applied to examples from the American Gothic by such authors as Henry James, Robert Bloch, Shirley Jackson, and Thomas Harris (Haefele-Thomas, 2017, p. 116). As Aldona Witkowska (2013) puts it:

[...] in the hands of American writers, the Gothic has gained a special character. [...] The emphasis on the family or pseudo-family issues [...] has its roots in the Puritan past, as colonists were to live in claustrophobic settlements and had to share the 'new world' with the 'devil servants,' who were lurking in the forest backwoods and mountain hideouts. [...] In the American Gothic, the family closeness is overwhelming too, the house [...] becomes a source of dysfunctionality, and the greatest danger comes from the family members or neighbours. [...] the American Gothic is a 'domesticated' version of the European one. It moves away from the ghosts in the castles to the ghosts of everyday life: haunted houses and disturbed families inside those houses (pp. 154-155).

These issues were widely present in the mid- $20^{\text {th }}$ century variations on the genre, which directly preceded Bellairs's original trilogy. ${ }^{16}$ The topic of the 'repressed' identity was then presented by, inter alia, using the characters of monster family members, supposed to hide their Otherness from the eyes of 'normal' people. One may point out such well-known TV series of the 1960s as The Addams Family (Levy, 1964-1966) and The Munsters (Connelly \& Mosher, 1964-1966) that, in a comic way, emphasised and subversively reflected on the central role of the house and the family motifs in the American Gothic (Witkowska, 2013, p. 155). This is especially important in the context of the myth of the ideal American family of the 1950s and 1960s, with its supposedly strict

16 Heinecken (2011), when discussing Bellairs's books, situates them also "against the mainstreaming of horror for adult audiences during the Post-Vietnam period [...] tied to the upheaval of traditional gender and sexual relations brought about by the feminist, antiwar, civil rights and gay rights movements [...] [that] radically transformed discourses surrounding masculinity" (p. 119). 
and stereotypical gender roles, which then prevailed in popular culture. ${ }^{17}$ Tison Pugh (2018) writes that "the [TV] monstrous and supernatural families [...] today read as allegories of gay lives lived in shadows, thereby expanding the vision of the American family to include the Other, even if these Others are exaggerated into cartoonish excess" (p. 59) ${ }_{1}^{18}$ which also applies to the book and, even more, to the film version of The House with a Clock in Its Walls.

The house and family are also the main areas of interest in Bellairs's series. "[...] like works of adult horror, the ['original'] trilogy is usefully understood as an exploration of the period's fears and anxieties related to gender and sexuality" (Heinecken, 2011, p. 119). In The House with a Clock in Its Walls, the prominent role is played by the titular mansion that is full of secret passages, mysterious doors, and serpentine corridors. It also has a basement - a typical Gothic motif and a powerful psychoanalytic analogue of the "unstable id," the "repressed unconscious" (Pheasant-Kelly, 2013, p. 191) - in which the climactic moment of the novel takes place, and where the 'uncanny' lies. The labyrinthine form of the building, as well as its vertical structure, can be read as symbolically referring to the secrets of the Barnavelt family members, Uncle Jonathan in particular. Just as the numinous clock is hidden somewhere in the house (it actually turns out to be concealed under the surface), Jonathan has to hide his magical abilities from the non-magical inhabitants of New Zebedee. He eventually 'comes out' as a warlock to Lewis but is initially presented as a person struggling with his true identity and with the mystery surrounding the mansion. He avoids talking to his nephew about what is going on in the house and behaves so strangely that it makes him resemble stereotypical Gothic villains, mysterious figures of a dual nature, seemingly ordinary people

17 These sitcoms presented families which were both 'normal' (consisting of heteronormative parents and their children, with some 'sidekick' representatives of the extended family) and 'abnormal' ('monstrous,' not corresponding to the ideal of what it means to be a 'standard' human).

18 This implicit mode of showing the Otherness has prepared a convenient ground for contemporary stories about haunting (or liberating) queerness and of non-normative monsters, including the human ones, 'coming out of the closet' (Benshoff, 1997), and for 'direct' popular culture images of queerness in many American Gothic and horror works, to mention FX's popular anthology series American Horror Story (Murphy \& Falchuk, 2011-Present), showing a gay couple, Patrick and Chad, struggling to live in a haunted mansion in the Murder House instalment, a lesbian, Lana Winters, locked in a terrifying mental institution in the Asylum season, or a bisexual vampire diva, the Countess Elizabeth, in the fifth incarnation of the anthology, Hotel (but also, as metaphors of the Otherness, a matriarchal community of witches hiding from the world and eventually 'coming out' in the Coven and Apocalypse parts, or a group - a 'family' - of 'human oddities' in Freak Show). 
but, secretly, suspicious individuals, often described as the torturers of orphans (Slany, 2016, p. 204). In the book by Bellairs (1973/1998b), we read as follows:

Creak, creak. Someone was tiptoeing down the hall. Lewis sat still and listened. [...] As slowly and carefully as he could, he tiptoed to the door. [...] The hall was dark, except for a glimmering gray window down at the far end. But Lewis could hear someone moving. And now he saw the faint, pale circle of a flashlight beam moving over the wallpaper. Frightened, Lewis pulled the door shut and then opened it just a crack. The flashlight beam had stopped. Now the figure with the flashlight brought his fist down on the wall - hard. [...] The figure pounded again, and again. Lewis stared and opened the door wider. Now the shadowy intruder stepped back, and Lewis saw a bulky shadow against the hall window. A bulky, bearded shadow with a pipe in its mouth. Jonathan! [...] A horrible thought came into his mind. Was Jonathan crazy? [emphases added]" (pp. 19-20).

As in traditional Gothic texts, including the American ones, "both overt and covert queer monstrosity often equated with mental illness" (Haefele-Thomas, 2017, p. 116), Lewis's reflection might lead to the interpretation of Jonathan as a person covering the 'repressed' homosexuality ${ }^{19}$ or, more broadly, queerness. It may therefore not be a coincidence that one of the first pieces of information about the boy's uncle that one can read in the novel is that: "Lewis had heard a few things about Uncle Jonathan, like that he smoked and drank and played poker. These were not such bad things in a Catholic family, but Lewis had two maiden aunts who were Baptists, and they had warned [emphasis added] him about Jonathan" (Bellairs, 1973/1998b, p. 4). This passage clearly helps to construct an image of this man as someone not corresponding to the ideals of the middle-class American family (not only of the late 40s, but also of the subsequent decades). After all, this character is far from the idea of 'normality.' Jonathan, of course, is a warlock - but he is also a single middle-aged man, living alone for many years, and befriending an elderly (also single) woman from the neighbourhood; he loves creating colourful illusions of which he is very proud too - but, at the same time, he always reminds Lewis and Rosa Rita that Mrs. Zimmerman is much more powerful than him. Referring to the relationship of Jonathan and his friend Florence, and to the one of the Izards, the novel antagonists, it is crucial to point out that in the book:

19 However, Jonathan confesses that he started learning magic "to impress a girl" (Bellairs 1973/1998b, p. 177). 
Destructive forms of magic are [...] linked to patriarchal forms of relations. Significantly, though Mrs. Izard is described as being a more powerful wizard than Isaac she remains mindlessly committed to the goals of her "Lord and Master" [(p. 171)]. The Izards' relationship clearly opposes that of the gender non-conforming Jonath[a]n and Mrs. Zimmerman, who share a bickering but mutually supportive relationship (Heinecken, 2011, p. 123).

In the film adaptation of Bellairs's novel, the portrayal of Jonathan, although relatively faithful to the book, is developed. Played by Jack Black, this character, as in the novel, is introduced to the viewers in the beginning. However, one can notice several significant changes in the presentation of Lewis's uncle from the first minutes of the picture. The book warlock had "a bushy red beard that was streaked in several places with white" and "Big Mac khaki trousers [...] bulged out in front by his pot belly," and was "wearing a gold-buttoned red vest over a blue work shirt" (Bellairs, 1973/1998b, p. 5). His cinematic equivalent is dressed much more flamboyantly and seems to be very interested in fashion: he has a fedora hat, a tawny port shirt, and a black garment with rich golden embroidery; his beard is well trimmed. Interestingly, when Lewis (Owen Vaccaro) and, later, Mrs. Hanchett (Colleen Camp) ${ }^{20}$ ask him whether he is wearing a robe, he proudly answers: "It's a kimono" (Fischer, Vanderbilt, Kripke, \& Roth, 2018). Jonathan's love for pompous style - or "a kitsch insanity" (Page-Kirby, 2018) - is also visible in the interior of his house, which is full of not only clocks, drowning the striking of the doomsday one, but also of patterned wallpapers, dark wood panels and stairs, ancient yet well-maintained furniture, expensive trinkets, etc. The mansion's garden, additionally, is very large and glamorous, with a unicorn-shaped fountain and colourful flowerbeds. Of course, the house was splendid in Bellairs's book too, with marble fireplaces and glazed bookcases inside but, in the film, Jonathan's connection to his property is especially strengthened by the fact that many items there are charmed so that they behave like living creatures, or even like pets deeply attached to their 'owner' (to mention a dog-like armchair and an animated topiary griffin).

Referring to popular culture portrayals of gay people, Mark McLelland (2005) writes that "homosexuality must be 'performed' by the iteration of codes and practices which signify 'homosexuality.' These are acted out with the body in certain stances, gestures, vocal intonations, glances and looks, on the body

20 Mrs. Hanchett, later exposed as a magically disguised evil witch, Mrs. Izard (Renée Elise Goldsberry), is presented in the film as a stereotypical, narrow-minded, nosy neighbour who does not tolerate Jonathan's behaviour, and even wonders if he should ever be a guardian of any "human child" (Fischer, Vanderbilt, Kripke, \& Roth, 2018). 
through hairstyle, grooming, fashion and accessories and around [emphases in original] the body through the styling of habitat" (p. 258). ${ }^{21}$ All of this can be found in the depiction of Jonathan Barnavelt in Roth's film, including in the over-the-top, mannerist, or ever campy way in which Jack Black plays the role - using exclamations, 'exaggerated' gestures and facial expressions, 'quirk' gazes, etc., conventionally linked with mainstream representations of queer men. Their other characteristics mentioned above (the association of homosexual males with fashion, style, and consumption), however stereotypical, in many texts of popular culture "render them of interest to women (who 'naturally' share these interests) and whose best friends they become" (p. 256), which, as one may argue, comes through in the friendship of Jonathan and Mrs. Zimmerman. It is worth noting that they are much more conventionally attractive in the film than in the book - especially the witch, played by Cate Blanchett, whose appearance (although her hair is dyed grey) moves away from the depiction of her character in the novels, where she has "one of the wrinkliest faces" (Bellairs, 1973/1998b, p. 10) that Lewis has ever seen; this may be considered as an attempt to position the adaptation as a more mainstream work than the novel. Additionally, by making Jonathan and Florence approximately the same age (both Black and Blanchett were born in 1969), the film initially suggests that they could have a 'traditional' romantic relationship. This is also what Lewis suspects in the beginning, but which is ridiculed by Mrs. Zimmerman: "Your uncle and I aren't anything kissy faced," and then commented by the boy himself: "The word is 'platonic" (Fischer, Vanderbilt, Kripke, \& Roth, 2018). ${ }^{22}$

Conversely, the film may be seen as implying Jonathan's romantic feelings for Isaac Izard (Kyle MacLachlan). Before WW2, they were friends performing together as a duo of magicians. As Mrs. Zimmerman informs Lewis:

Isaac was an orphan. And Jonathan, a runaway. Neither of them had family. All they had was magic. And each other. Then, Isaac went away to war. [...] Then, suddenly, Isaac came back home. But it wasn't the same Isaac. He was different. And angry. And more powerful than any warlock had the right to be. [...] he was lost in the Black Forest. Now, that is a very old place with very old magic. It's where the Brothers Grimm wrote their histories. [...] we think that Isaac met a dark warlock

21 See also Butler (1990/2006).

${ }^{22}$ In the novel, Lewis is upset when his friend suggests a romance between Jonathan and Florence: "'And how come old Mrs. Zimmermann is over there all the time? Is she in luuvv [emphasis in original] with him?' Tarby threw his arms around the stone tree and started kissing it with loud smacks. Lewis felt like crying, but somehow he managed to keep down the tears" (Bellairs, 1973/1998b, p. 65). 
in those woods [...] who gave him some terrifying, forbidden books. [...] Then, Isaac abandoned poor Jonathan. No explanation. And he found himself a witch. Selena. So spiteful and mean, he married her. And they locked themselves away in the house (Fischer, Vanderbilt, Kripke, \& Roth, 2018). ${ }^{23}$

This story of Isaac - and his wife - differs from the one presented in the novel. ${ }^{24}$ Jonathan's deep feelings for his friend are highlighted as well as the end of a 'bromance' or even a romance between Barnavelt and Izard. What is interesting is that their friendship had lasted until the warlock came back from the war with Selena - a woman he eventually married. We may thereby speculate whether it was the magician's wife who actually destroyed the relationship. ${ }^{25}$ Lewis's uncle seems to be as haunted by the doomsday chronometer as by the vision of Isaac and Selena as lovers: in one scene, he wakes up when the hidden clock strikes and there is a change of shot from his frightened face to the evil couple's portrait, found by Jonathan in a terrifying room full of broken dolls and skeletons.

However, in the context of the books, it is Lewis himself and also Rose Rita who are mainly discussed as (proto-)queer characters. Melynda Huskey (2011), when interpreting Bellairs's novels as representatives of, as she calls it, the "queer-kid Gothic," points out that the 'original' trilogy exploits "the affinity of the Gothic with the queer" to "explore the identity development of non-gender-conforming kids." Heinecken (2011) also stresses the fact that "Bellairs presents Lewis as a queer boy" (p. 120), and Rosa Rita as wishing to "stay outside the heterosexual matrix" (p. 129). To argue their theses, both critics frequently refer to the application of queer theory to the Gothic and the horror genre. Heinecken, on

23 The witch's name is spelled 'Selena' in the film's closing credits and 'Selenna' in the book.

${ }^{24}$ In the words of Jonathan: "Isaac [...] fooled around with black magic, the worst kind of thing a wizard can do. [...] I'd say he was [...] very evil [...]. Mrs. Zimmermann thinks so too. [...] there were many evenings when she and I would stand in her back yard and look up and see old Isaac's evil face in the window of the cupola on top of the house. [...] Old Isaac died during a wild thunderstorm, one of the worst in the history of Capharnaum County. You can look it up in the New Zebedee Chronicle if you want to: roofs blown off barns, trees uprooted, and a bolt of lightning melted the iron doors on the tomb Isaac is buried in now. [...] She [Selenna] died before he did. [...] [She was] pretty strange, as you'd have to be to choose Isaac Izard for a husband" (Bellairs, 1973/1998b, pp. 35-36).

25 It can thereby not be a coincidence that she appears right after Mr. Izard met a dark magic teacher in the Black Forest. The latter one, interestingly, is later exposed as a Hebrew demon named Azazel, who "'taught men to fashion swords and shields' while women learned from him 'finery and the art of beautifying the eyelids"' (Davidson, 1967, p. 63); a seducer himself, Azazel was also told to have been a fallen angel, seduced by either human women or the demonesses: Naamah, Agrat daughter of Magrat, and Lilith (Graves \& Patai, 1963/2005, p. 100-101). 
the one hand, notes that The House with a Clock in Its Walls "draws on [G]othic tropes concerned with the exploration of repressed emotions and forbidden desires related to gender and sexuality [...]. Like the house, Lewis is haunted by his past: an orphan, he fears rejection by his new guardian. However[,] he is most haunted by his own desires to achieve a conventional masculine identity and to bond with other boys" (p. 120). Huskey (2011), on the other hand, compares the first novel's plot to well-known components of supernatural narratives:

Structurally, Lewis is a Gothic heroine. Orphaned by a midnight accident and cut off from his old life, he travels to a remote town where he lives with his mysterious guardian in a splendid mansion with a supernatural curse. [...] He seeks the affections of a cold, insulting, hyper-masculine figure of romance - Tarby, the class troublemaker [...]. His misplaced affections lead him into disastrous attempts to prove his love.

Heinecken (2011) also discusses Lewis's feelings towards Tarby, the diegetic embodiment of stereotypical and hegemonic hyper-masculinity - she writes that:

[...] Lewis's desire to be like the athletically gifted Tarby is inextricable with his desire to have Tarby, to be more permanently linked to him. [...] He asks Jonath[a]n to perform an eclipse of the moon, a spell notable for heightening Lewis' senses [...]. Tarby, however, is clearly repelled by the spell's effects. [...] Lewis concocts a desperate plan to impress him by raising a spirit on Halloween night [...] and Mrs. Izard is released from her grave. [...] the traditional masculinity supposedly embodied by Tarby turns out to be sham. Unlike Lewis, Tarby does not have the courage to confront the evils the boys have wakened, but, in a scene recalling the homoerotic denial of some men, runs away in terror while threatening to break Lewis' arms if he reveals his participation in the resurrection [...]. His mother later admits that he remains tormented by nightmares (p. 121, pp. 123-124).

In the film, Lewis - thinner but nerdier than in the books, and with a taste for wearing colourful bow-ties - tries to befriend the sporty boy as well. Tarby (Sunny Suljic) is introduced to the viewers during a P.E. lesson scene as the only person who is nice to the protagonist. The film presents him as a classic James Dean-style 'bad boy': in a pompadour haircut and a casual white t-shirt, or simply dressed in a sport hoodie. ${ }^{26}$ In one meaningful scene, Lewis seems to be charmed by his

26 Tarby's resemblance to James Dean was also commented on by the film's creators in the bonus materials for the $4 \mathrm{~K}$ Ultra HD, Blu-ray, DVD, and Digital releases of The House with a Clock in Its Walls. 
appearance and, accompanied by similarly attracted kids, watches the other boy practising baseball. Young Barnavelt is captivated by his new colleague's look and physical skills, and evidently admires the hyper-ladness embodied by Tarby.

In Roth's picture, Lewis is also - literally - haunted by some well-known representations of stereotypical masculinity: a cowboy on the stained glass in the mansion and an animated knight armour. However, there is a positively presented masculine pop culture persona in the film: a superhero from the boy's favourite TV series, Captain Midnight (Bilson, 1954-1956). Lewis wears big goggles, the same as this character wears - in this case, these do not symbolise hegemonic yet toxic masculinity, but the boy's peculiar interest in nerdy works of culture. Tarby suggests Lewis should stop sporting this 'weird' eyewear: "I just think it might be easier for you if you lost the goggles. Acted a little more, you know, normal" (Fischer, Vanderbilt, Kripke, \& Roth, 2018). Interestingly, as the protagonist eventually rejects the ideal personified by his former companion, he returns to wearing goggles, and actually uses them as one of the requisites to find the doomsday clock and defeat Mr. and Mrs. Izard. In the film's ending, Tarby is alone and sad, looking at happy Lewis, Uncle Jonathan, and Mrs. Zimmerman with regret. Young Barnavelt, conversely, is relived: he tells his companions that he has a new friend, Rose Rita (Vanessa Anne Williams) and, when asked by Florence: "Is it kissy-faced?," he answers: "No, platonic," thereby referring to his previous conversation with the witch and confirming that he started the process of accepting his own version of masculinity.

\section{Conclusions: The Bevy of Black Swans}

Dawn Heinecken (2011) states that: "John Bellairs worked to challenge existing gender norms through the construction of shy, clumsy loners as his protagonists. Like other forms of children's literature emerging in the seventies, his works of children's horror are particularly reflective of the period's changing discourses around masculinity" (p. 129). The scholar, referring to all three books in the 'original' trilogy, discusses them as revealing "a similar pattern of masculine revision and feminine displacement at work in children's literature" (p. 120). In The House with a Clock in Its Walls, she argues, Lewis's quest is to "restore the order," which "at the surface level [...] requires the young queer boy to triumph over an evil that takes a specifically female form" (p. 121) of Mrs. Izard, ${ }^{27}$ resur-

\footnotetext{
27 'In many ways Lewis' confrontation with Mrs. Izard follows a traditional narrative pattern in which the male hero restores order and establishes the correct gender identity via reclaiming
} 
rected by him and Tarby. However, on a deeper level, Bellairs's work offers "the happy resolution [...] when Lewis is finally able to recognize and destroy the true source of terrifying evil [Isaac Izard] and embrace a different kind of masculinity aligned with life affirming magic and a female best friend" (p. 124).

It is also worth noting that Rose Rita has her own struggles with the era's ideal of what it means to be a 'girl' in the subsequent books in the series, especially in The Letter, the Witch, and the Ring (Bellairs, 1976/1998c), in which she "looks for a magical escape from conventional femininity as she approaches adolescence" (Heinecken, 2011). ${ }^{28}$ It is surprising then that in the film Rosa Rita always wears skirts, preppy cardigans, and a ribbon in her hair - also pink ones - which makes her far more stereotypically 'girlish' than her book predecessor. Heinecken (2011) writes that:

Despite the apparent gender nonconformism of his characters, women and the feminine are closely related to the monstrous in Bellairs' trilogy, and ultimately female identity remains linked to loss and uncertainty. [...] Finally published 17 years after the original trilogy, it is notable that the central narrative of The Ghost in the Mirror [completed by Strickland] involves the restoration of Mrs. Zimmerman's powers. While children's horror of the seventies suggested the need for a refreshed, renewed masculinity, it was left up to later works of horror to formulate power as a necessary ingredient of femininity (pp. 129-130).

Having said this, it is unfortunate that in the 2018 film the viewers are faced with a much more conservative vision of women and girls than in the books which is visible not only in the portrayal of Rose Rita, but also in conventional images of Mrs. Izard as a female monster and of Mrs. Zimmerman as a witch deprived of full power - and, also, a younger and more beautiful one, and mourning her dead husband and children, of which there was no information

the gaze and defeating the castrating threat of the female. Similarly, the restoration of male power seems linked to a restructuring and straightening of Lewis's desire. At the end of the novel, he announces to Jonath[a]n that he has given up the quest for Tarby after realizing 'We're not the same type,' and that he has secretly found a new best friend, a girl named Rose Rita Pottinger ([Bellairs, 1973/1998b,] p. 178). Yet while normative relations of gender and sexuality appear to be reinscribed at certain levels of the text, to read the novel as primarily tracing a defeat of queerness and monstrous femininity is to ignore the critique of traditional forms of masculinity underscoring its narrative" (Heinecken, 2011, p. 123). It is also worth noting that, in the film, Selena Izard pretends to be Lewis's mother, comes to him in the night, and suggests making dangerous things that would lead to the resurrection of her husband Isaac (in the book, Lewis saw only a phantom of his dead Aunt Mattie).

28 See also Heinecken (2011, pp. 124-130) and Schmidt (1987, pp. 42-43). 
in Bellairs's novels (although there was a hint that she was in love with a boy named Mordecai Hunks).

Nevertheless, it can be argued that both the novel and the film, despite their flaws when it comes to the portrayals of femininity, actually succeed when it comes to the presentation of their main idea: the conviction that Otherness should be highly appreciated and valued. This also applies to the background characters from the series' next volumes, like simple-minded Aggie from The Letter, the Witch, and the Ring (Bellairs, 1976/1998c), an elderly warlock who is not taken seriously, Grandpa Drexel from The Ghost in the Mirror (Bellairs \& Strickland, 1993a), or visually impaired Bertie from The Vengeance of the Witch-Finder (Bellairs \& Strickland, 1993b). Not all of these characters can be interpreted as queer, but they are all 'different' in their own ways, and every one of them is somehow included in a non-traditional family - a chosen family in a queer theory sense - started by Lewis, Uncle Jonathan and Mrs. Zimmerman, as it is explicitly shown on the stained-glass image at the end of Roth's film.

This appreciation of Otherness is particularly stressed in a short yet powerful scene from the film, covering Lewis's and Jonathan's conversation (not present in the book):

\section{Lewis: Uncle Jonathan?}

Jonathan: Hmm?

Lewis: [...] I just wish that I met you a long time ago.

Jonathan: Yeah, me, too. Good night.

Lewis: Why didn't I? How come you left home?

Jonathan: Well... Truth is, my father, your grandpa, didn't like magic. And he sure didn't like me messing around with it. We fought about it and... And we fought some more, until finally I just took off. I was the black swan of the family. Lewis: It's a black sheep.

Jonathan: Hmm, pretty sure it's 'swan.'

Lewis: [...] Uncle Jonathan? I think... I think that I might be a black swan, too. Jonathan: Well, then I guess we're a flock of swans.

Lewis: A bevy. It's called a bevy of swans (Fischer, Vanderbilt, Kripke, \& Roth, 2018).

This dialogue, while explicitly alluding to performing magic by Jonathan, can also be read as a conversation of two queers. Both Lewis and his uncle - notably rejected by his father who did not accept his identity - are different than other men and boys, which made people in their milieu react with reserve or mockery, or even in a hostile way towards them. But the Barnavelts can benefit from this Otherness in many ways. Sometimes it can work to their advantage, 
as in the scene where Jonathan conjures colourful tissues to wipe Lewis's tears. It may be amusing, like when the boy magically transforms a ginger cat into a rainbow-coloured one (the mentioned tissues are, in fact, in the colours of the rainbow too; when taken together, these may be seen as queer symbols). But, most importantly, the Otherness has the power to save lives, as it is only due to Lewis's unconventional way of thinking and performing magic that the boy and his friends, and the whole world, are saved from doom. As same as the film, the novel, by:

Revealing Isaac as the true source of death and terror, [...] also critiques traditional masculine values through its construction of magic. Though magic can be practiced by both males and females, evil magic is hyper rational [...]. While Izard's rational magic is irrationally aimed at destroying the world, the protagonists' magic is life affirming and illogical; they successfully track down the clock by having Lewis 'dream up the silliest set of instructions' [(Bellairs, 1973/1998b, p. 157)] he can think of [...] (Heinecken, 2011, p. 123). ${ }^{29}$

Annette Wannamaker (2008), referring to J. K. Rowling's Wizarding World, coins the term "witchy masculinity" (p. 130) that includes positively portrayed "unconventionally masculine behaviors" (p. 143). This also applies to Lewis and Jonathan - weird, peculiar, nerdy, stylish, campy, caring, fragile, compassionate... and queer heroes of Bellairs's book and Roth's film. After all, is there anything queerer than magic?

\section{References}

Abbruscato, J., \& Jones, T. (Eds.). (2014). The Gothic fairy tale in young adult literature: Essays on stories from Grimm to Gaiman. Jefferson, NC: McFarland.

Aguirre, M. (1990). The closed space: Horror literature and Western symbolism. Manchester: Manchester University Press.

Asselin, D., Asselin, P. (Producers), \& Cox, N. (Director). (1979). Vincent Price’s Once upon a midnight scary [Television film]. New York, NY: CBS.

29 This power of being different was also noticed by one of the film's reviewers: "We need kids who $[. .$.$] can look at what is and adapt to fit their strengths. We need more Jonathans$ [...] who can set kids free and let them fail. We need fewer kids (and adults) who think that different is synonymous with wrong. And, most of all, we need more Lewises, kids who become comfortable enough to know that what makes them offbeat is what makes them strong. We need more weirdos" (Page-Kirby, 2018). 
Abate, M. A., \& Kidd, K. (Eds.). (2011). Over the rainbow: Queer children's and young adult literature. Ann Arbor, MI: University of Michigan Press.

Beauvais, C. (2015). The mighty child: Time and power in children's literature. https:// doi.org/10.1075/clcc.4.

Bellairs, J. (1998a). The figure in the shadows. In The best of John Bellairs. New York, NY: Barnes \& Noble. (Original work published 1975).

Bellairs, J. (1998b). The house with a clock in its walls. In The best of John Bellairs. New York, NY: Barnes \& Noble. (Original work published 1973).

Bellairs, J. (1998c). The letter, the witch, and the ring. In The best of John Bellairs. New York, NY: Barnes and Noble. (Original work published 1976).

Bellairs, J., \& Strickland, B. (1993a). The ghost in the mirror. New York, NY: Dial Books for Young Readers.

Bellairs, J., \& Strickland, B. (1993b). The vengeance of the witch-finder. New York, NY: Dial Books for Young Readers.

Bellairs, J., \& Strickland, B. (1995). The doom of the haunted opera. New York, NY: Dial Books for Young Readers.

Benshoff, H. M. (1997). Monsters in the closet: Homosexuality and the horror film. Manchester: Manchester University Press.

Berman, S. (2018, September 21). Re: The genius of John Bellairs's The House with a Clock in Its Walls [Web article comment]. Retrieved from https://www.tor. com/2018/09/21/the-genius-of-john-bellairss-the-house-with-a-clock-in-itswalls/.

Bilson, G. (Producer). (1954-1956). Captain Midnight [Television series]. Los Angeles, CA: CBS.

Bishop, C. (2018). Necromancy, demons and demonic possession, witches, occult... [Film review: The House with a Clock in Its Walls]. Christian Answers. Retrieved from https://christiananswers.net/spotlight/movies/2018/housewithaclockinitswalls 2018.html.

Bloom, C. (2012). Horror fiction: In search of a definition. In D. Punter (Ed.), A new companion to the Gothic (pp. 211-223). https://doi.org/10.1002/9781444354959.ch15.

Bond Stockton, K. (2009). The queer child, or growing sideways in the twentieth century. Durham, NC: Duke University Press.

Browning, J. E. (2017). Horror criticism. In M. Cardin (Ed.), Horror literature through history: An Encyclopedia of the stories that speak to our deepest fears (Vol. 1, pp. 97-101). Santa Barbara, CA \& Denver, CO: Greenwood.

Broughton, M. A. (2001). Bellairs, John. In B. E. Cullinan \& D. G. Person (Eds.), The Continuum encyclopedia of children's literature (pp. 72-73). New York, NY \& London: Continuum.

Bruhm, S., \& Hurley, N. (Eds.). (2004). Curiouser: On the queerness of children. Minneapolis, MN \& London: University of Minnesota Press. 
Butler, J. (2006). Gender trouble: Feminism and subversion of identity. New York, NY \& London: Routledge. (Original work published 1990).

Chambliss, A., Wolkoff, B. (Writers), \& La Salle, E. (Director). (2016). Ruby slippers [Television series episode]. In E. Kitsis \& A. Horowitz (Producers), Once upon a time. Burbank, CA: ABC.

Chubb, L. (2016, April 24). One Million Moms protest lesbian kiss on family-friendly TV show Once Upon a Time. Gay Star News. Retrieved from https://www.gaystarnews.com/article/one-million-moms-lesbian-kiss/\#gs.wRqrvKE.

Connelly, J., \& Mosher, B. (Producers). (1964-1966). The Munsters [Television series]. Los Angeles, CA: CBS.

Davidson, G. (1967). Azazel. In A dictionary of angels: Including the fallen angels (pp. 63-64). New York, NY: The Free Press.

Demory, P. (2018). Queer adaptation. In D. Cutchins, K. Krebs, \& E. Voigts (Eds.), The Routledge companion to adaptation (pp. 146-156). https://oi. org/10.4324/9781315690254-17.

Doty, A. (1993). Making things perfectly queer. Interpreting mass culture. Minneapolis, MN \& London: University of Minnesota Press.

Duffy M. J. (2004) Mystery, the genetic system, and children's books. Analecta Husserliana, 82, 193-213. https://doi.org/10.1007/978-94-007-1017-7_14.

Fischer, B. J., Vanderbilt, J., Kripke, E. (Producers), \& Roth, E. (Director). (2018). The house with a clock in its walls [Motion picture]. United States: Universal Pictures.

Graves, R., \& Patai, R. (2005). The Sons of God and the Daughters of Men. In Hebrew myths: The book of Genesis (R. A. Davis, ed.). Manchester: Carcenet. (Original work published 1963).

Haefele-Thomas, A. (2017). Queer American Gothic. In J. A. Weinstock (Ed.), The Cambridge companion to American Gothic (pp. 115-127). https://oi. org/10.1017/9781316337998.009.

Haggerty, G. E. (2016). Queer Gothic. Urbana, IL \& Chicago, IL: University of Illinois Press.

Hahn, D. (2015). Bellairs, John. In The Oxford companion to children's literature ( $2^{\text {nd }}$ ed., p. 62), Oxford: Oxford University Press.

Heinecken, D. (2011). Haunting masculinity and frightening femininity: The novels of John Bellairs. Children's Literature in Education, 42(2), 118-131. https://doi. org/10.1007/s10583-010-9127-7.

Heinecken, D. (2014). My monster myself: Recuperating the maternal in early children's horror by Zilpha Keatley Snyder and Phyllis Reynolds Naylor. Children's Literature Association Quarterly, 39(1), 68-87. https://doi.org/10.1353/chq.2014.0020.

Helman, A., \& Osadnik, W. M. (1996). Film and literature: Historical models of film adaptation and a proposal for a (poly)system approach. Canadian Review of Comparative Literature, 23(2), 645-657. 
Hendrix, G. (2018, September 21). The genius of John Bellairs's The House with a Clock in Its Walls. Tor.com. Retrieved from https://www.tor.com/2018/09/21/the-genius-ofjohn-bellairss-the-house-with-a-clock-in-its-walls/. (Original work published 2013).

Hoberman, D., Lieberman, T. (Producers), \& Condon, B. (Director). (2017). Beauty and the Beast [Motion picture]. United States: Walt Disney Studios Motion Pictures.

Hogle, J. E. (2002). Introduction: The Gothic in Western culture. In J. E. Hogle (Ed.), The Cambridge companion to Gothic fiction (pp. 1-20). https://doi.org/10.1017/ CCOL0521791243.001.

Huskey, M. (2010). A specter is haunting New Zebedee: Reading John Bellairs as queerkid gothic. Poster session presented at the Washington State University Academic Showcase, Pullman, WA. Retrieved from https://research.libraries.wsu.edu/xmlui/ bitstream/handle/2376/2357/Huskey - Specter is haunting.pdf?sequence=1.

Illuminati, V. (2016). “Speak to Me in Capital Letters!": Same-sex parenting, new families and homosexuality in Italian and translated picturebooks by Lo Stampatello. In A. M. Ramos, S. Mourão, \& M. T. Cortez (Eds.), Fractures and disruptions in children's literature (pp. 228-243). Newcastle upon Tyne: Cambridge Scholars.

Jackson, A., Coats, K., \& McGillis, R. (Eds.). (2008). The Gothic in children's literature: Haunting the borders. New York, NY \& London: Routledge.

Jarkovská, L. (2014). Children's literature and the politics of gender. Journal of Gender and Power, 2(2), 73-82.

Kehily, M. J., \& Montgomery, H. (2009). Innocence and experience: A historical approach to childhood and sexuality. In M. J. Kehily (Ed.), An introduction to childhood studies: Second edition (pp. 70-89). New York, NY: Open University Press.

Kidd, K. B. (2004). Making American boys: Boyology and the feral tale. Minneapolis, MN \& London: University of Minnesota Press.

Kidd, K. (2011). Queer theory's child and children's literature studies. PMLA, 126(1), 182-188. https://doi.org/10.1632/pmla.2011.126.1.182.

Kincaid, J. R. (1992). Child-loving: The erotic child and Victorian culture. New York, NY \& London: Routledge.

Lesnik-Oberstein, K. (2016). Children's literature: Sexual identity, gender and childhood. Breac, 6. Retrieved from https://breac.nd.edu/articles/childrens-literaturesexual-identity-gender-and-childhood/.

Lesnik-Oberstein, K., \& Thomson, S. (2002). What is queer theory doing with the child?. Parallax, 8(1), 35-46. https://doi.org/10.1080/13534640110119605.

Levy, D. (Producer). (1964-1966). The Addams family [Television series]. Los Angeles, CA: ABC.

McCort, J. R. (Ed.). (2016). Reading in the dark: Horror in children's literature and culture. Jackson, MS: University Press of Mississippi.

McElmeel, S. L. (1999). John Bellairs. In 100 Most Popular Children's Authors: Biographical Sketches and Bibliographies (pp. 30-34). Englewood, CO: Libraries Unlimited. 
McLelland, M. (2005). Inside out: Queer theory and popular culture. In E. Mackinlay, E. Collins, \& S. Owens (Eds.), Aesthetics and experience in music performance (pp. 255-265). Newcastle: Cambridge Scholars Press.

Moon, M. (1998). A small boy and others: Imitation and initiation in American culture from Henry James to Andy Warhol. Durham, NC: Duke University Press.

Mumford, G. (2017, March 16). Beauty and the Beast: Disney refuses to cut gay scene for Malaysian release. The Guardian. Retrieved from https://www.theguardian. com/film/2017/mar/16/beauty-and-the-beast-disney-gay-scene-malaysia.

Murphy, R., \& Falchuk, B. (Producers). (2011-Present). American horror story [Television series]. Los Angeles, CA: FX.

Nikolajeva, M. (2010). Power, voice and subjectivity in literature for young readers. New York, NY \& London: Routledge.

Oittinen, R. (2006). Adaptation. In J. Zipes (Ed.), The Oxford encyclopedia of children's literature (vol. 1, p. 10). Oxford: Oxford University Press.

Page-Kirby, K. (2018, September 20). A weirdo finds his power in The House with a Clock in Its Walls. The Washington Post. Retrieved from https://www.washingtonpost.com/express/2018/09/20/weirdo-finds-his-power-house-with-clock-itswalls/?utm_term $=.7 \mathrm{a} 4613 \mathrm{bcfffa}$.

Perdzyńska, K. (2010). Czyje online disinhibition? Wojny kulturowe o status homoseksualizmu. In Ł. Kapralska \& B. Pactwa (Eds.), Agora czy Hyde Park? Internet jako przestrzeń społeczna grup mniejszościowych (pp. 335-371). Kraków: Nomos.

Pheasant-Kelly, F. (2013). Abject spaces in American cinema: Institutional settings, identity and psychoanalysis in film. London \& New York, NY: I. B. Tauris.

Pugh, T. (2011). Innocence, heterosexuality, and the queerness of children's literature. https://doi.org/10.4324/9780203831410.

Pugh, T. (2018). The queer fantasies of the American family sitcom. DOI: $10.2307 / \mathrm{j}$. cttltrkkgj.

Raghavan, S. (2017, March 22). Disney's hit Beauty and the Beast is banned in Kuwait for its 'gay moment.' The Washington Post. Retrieved from https://www.washingtonpost.com/news/worldviews/wp/2017/03/22/disneys-hit-beauty-and-the-beastis-banned-in-kuwait-for-its-gay-moment/?utm_term=.314f7b5e15b8.

Rose, J. (1984). The case of Peter Pan, or the impossibility of children's fiction. London: Macmillan.

Schmidt, G. D. (1987). See how they grow: Character development in children's series books. Children's Literature in Education, 18(1), 34-44. https://doi.org/10.1007/ $\underline{B F 01135437 .}$

Sedgwick, E.K. (1985). Toward the Gothic: Terrorism and homosexual panic. In Between men: English literature and male homosexual desire (pp. 83-96). New York, NY: Columbia University Press. 
Sedgwick, E.K. (1991). How to bring your kids up gay: The war on effeminate boys. Social Text, 29, 18-27. https://doi.org/10.2307/466296.

Skowera, M. (2016). Cthulhu dla dzieci. Nawiązania do twórczości H. P. Lovecrafta w serii Johna Bellairsa i Brada Stricklanda o Luisie Barnavelcie. Creatio Fantastica, 3-4(54-55), 19-37.

Slany, K. (2016). Groza w literaturze dziecięcej. Od Grimmów do Gaimana. Kraków: WN UP.

Sobolczyk, P. (2014). Queer gothic - queer modernism. Poznańskie Studia Polonistyczne. Seria Literacka, 24(44), 71-93. https://doi.org/10.14746/pspsl.2014.24.5.

Strickland, B. (1998). The specter from the magician's museum. New York, NY: Dial Books for Young Readers.

Strickland, B. (2000). The beast under the wizard's bridge. New York, NY: Dial Books for Young Readers.

Strickland, B. (2001). The tower at the end of the world. New York, NY: Dial Books for Young Readers.

Strickland, B. (2003). The whistle, the grave, and the ghost. New York, NY: Dial Books for Young Readers.

Strickland, B. (2006) The house where nobody lived. New York, NY: Dial Books for Young Readers.

Strickland, B. (2008). The sign of the sinister sorcerer. New York, NY: Dial Books for Young Readers.

Vassiloudi, V. (2016). (En)gendering children's literature in the Western paradigm: What the critics don't tell us about gender... Asian Women, 32(4), 23-43.

Wannamaker, A. (2008). Boys in children's literature and popular culture: Masculinity, abjection, and the fictional child. New York, NY \& London: Routledge.

Warner, M. (1991). Introduction: Fear of a queer planet. Social Text, 29, 3-17.

Wein, E. (2000). Mystery in a house. The Lion and the Unicorn 24(2), 247-259. https:// doi.org/10.1353/uni.2000.0024.

Witkowska, A. (2013). American Gothic, czyli horror amerykańskiego domostwa. Analiza „udomowionej”, amerykańskiej wersji gotyku na przykładzie seriali American Gothic i American Horror Story. Media - Kultura - Komunikacja Społeczna, 9, 154-162. 